\title{
Spatial Delineation of Gold Resource Planning Regions Based on Multi-Objectives
}

\author{
Yuhan Zhang \\ Chinese Academy of Natural Resources Economics, China \\ Corresponding author: zhangyuhanwinter@sina.com
}

Article received: 10 November 2020, revised: 25 July 2021, accepted: 18 September 2021

DOI: $10.51835 /$ ijeg.2021.1.1.2

\begin{abstract}
Current gold resource management in China has faced dual challenge from guaranteeing metal supply (quantity) and resource upgrade and transformation (quality). Although China has proposed the setup of seven gold resource planning regions to resolve this challenge, how to spatially-delineate these regions has not been specified. In this study, we identify three criteria for the spatial delineation of these 7 planning regions, i.e., (i) geographic distance from any mining right to the center of its planning region is shorter than to the center of any adjacent planning region; (ii) the size of each planning region should be similar; (iii) the amount of gold production capacity in each planning region should reach a certain proportion threshold of the national total (namely the "goal value"). Referenced from the existing spatial delineation methods, Voronoi diagram and buffer analysis are used to calculate the spatial scope necessary to satisfy these three objectives, from both resource development (mining right-level) and management (administrative county-level) perspective. The results show that with the goal value rising from 40 to $60 \%$, the planning region size, the number of mining right and the administrative county involved in the planning regions all increase substantially, but the growth rates are different. Our work integrates the mineral resource management and geographic analysis, and such methodology is also applicable on other commodities.
\end{abstract}

Keywords: China; gold resource planning regions; spatial delineation; Voronoi diagram; buffer analysis

\section{INTRODUCTION}

Gold is a key strategic metal, and is indispensable for national economic and social development (Pian and Santosh, 2019). In China, since the Open-Door policy in 1978, gold mining has provided crucial support to the rapid economic growth and infrastructure buildup (Meng et al., 2018). However, under the current transformation of the Chinese economic development mode, ecological/environmental protection has faced unprecedented challenges (Wang and Chen, 2019). With gradual implementation of various ecological/environmental protection polices and conservation areas setup, the Chinese gold mineral industry has to transform from the previous small-scale, scattered and less- organized mining (Zhu, 2016) into more-integrated green exploitation (Shen et al., 2016). Stable gold supply is indispensable for China's economic and social development (Shen et al., 2018). In the year 2018, gold consumption in China was $1151.4 \mathrm{t}$, accounting for $26.5 \%$ of the global total, and ranking the world's first in six consecutive years (Guo et al., 2019). Moreover, China has increased its external gold dependency to over 50\% in 2018 (Wang et al., 2019). The primary means to safeguard the gold resources supply is to ensure selfsufficiency and effectively utilization on the domestic resources (Daw, 2017). Taken 
together, China is facing dual pressure from guaranteeing gold resource supply and production upgrade and transformation. To resolve these problems in an integrated way, the National Mineral Resources Plan (20162020) was proposed in 2016 by the People's Republic of China (PRC) State Council (PRC State Council, 2016), which put forward a goal to establish 7 gold resource planning regions. These planning regions comprise key mineral zones and belts with favorable metallogenic conditions, sizable resources and good prospecting potential $(\mathrm{Wu}$ and Zhang, 2019).

Delineation of key regions and spatial regulation development are effective means for natural resources management, ecological/environmental protection, spatial resource development/conservation planning, and urban development optimization. For example, in terms of environmental protection, delineation of natural protection zones and formulation of strict management policies is one of major initiatives for many countries in ecological/environmental protection (Shafer, 1999; Shelford, 1941; UNESCO, 1974). In terms of biodiversity protection, identification of important areas is the primary step to formulate and implement protection plans (Knight et al., 2008). To maximize the protection effect with limited investment (Myers et al., 2000; Roberts, 2002), many countries have delineated prime protection areas of biodiversity protection (Blasi et al., 2011; Schouten et al., 2010). In terms of spatial planning, countries such as Germany, U.K. and Japan have paid more attention to problem-based policy area delineation (European Commission, 1999; Koyama, 2011). For example, to facilitate balanced development, Germany divided its major cities into three groups that need special development, optimized development and special ease (Blotevogel, 2006). In terms of mineral resource management, wellendowed countries such as the UK, US, Russia, Canada, and Australia tend to pay more attention to the spatial governance of mineral resources development, which evokes the idea of partition management (Wagner et al.,2006; Scott and Dimitrakopoulos, 2001; Makarov, 2009). From the published studies, it is found that regardless of the resources, environment or urban development, partition management policy tends to require a definite spatial scale, thus, spatial boundary delineation is critical for resource management. Policy implementation involves the process of spatial resource allocation $(\mathrm{He}$ et al., 2019).

Gold resource planning regions are key regions of Chinese gold distribution, and are important policy tools for partition management; their essence is the carrier of mineral resource management system. Amiri et al. (2019) demonstrated that system quality enhancement can facilitate more-effective natural resources utilization, strengthen the progress of the manufacturing industry, thus, facilitate higher economic growth. However, to the best of our knowledge, since the concept is relatively new, the 7 gold resource planning regions have only names, their spatial scope is not well defined, which create problems for effective resource management. There is only a small amount of research on this topic, and the delineation work is largely qualitative (Ma, 2015; Luo et al., 2016; Wang and Niu, 2016). The significance of this study is to use a quantitative method to calculate the spatial scope of gold resource planning regions in China based on multiple objectives, and propose the boundaries both for establishing and managing these gold 
resource planning regions. The former refers to the mining districts that the planning regions contain, and the latter refers to the county-level administrative regions that the planning regions involved. Making the gold resource planning regions become the real space policy area, so that the government can formulate special policies for specific mining rights in the planning regions to bring their roles into full play.

The chapter structures are arranged as follows: part II is the literature review of mineral spatial policy areas in and outside China, and the current methods for delineation of spatial policy areas; part III is the design of methods to delineate iron ore resource planning regions; part IV is the analysis results and discussion; part $\mathrm{V}$ is the conclusion and suggestions on policy making.

\section{Literature Review}

The spatial area for mineral resource management is very popular internationally, most of the countries define policy areas to protect important domestic mineral resources from disturbing by other construction activities. In the UK, Mineral Safeguarding Areas is delineated to maintain an adequate and steady supply of energy, construction and industrial minerals that can be indigenously produced (Wrighton et al, 2014; Weber et al., 2008; McEvoy et al., 2007). In addition to the safeguarding areas, some local mineral resource plan in the UK also requires the delineation of areas for future working, including Specific Sites, Preferred Areas and Areas of Search (Shropshire County Council and Telford \& Wrekin Council, 2000). The United States also pays great attention to the protection of mineral resources for utilization. In Carroll County, Maryland, Mineral Resource Overlay (MRO) zones are imposed on other zoning districts where mining is seen as a compatible activity and there are known economic mineral resources present (Dunn et al., 1980; Carroll et al. 1999). In Queensland and Western Australia, significant resource areas identified as Key Resource Areas (KRAs) and Priority Resource Locations (PRLs) respectively, which are protect from development that is incompatible with extraction (Baker and Hendy, 2005). In order to guarantee the stable development of domestic metal industry, the former Soviet Union built a number of mineral supply areas (Е.И., 1985).

The partition management of China's mineral resource date back to the beginning of 21 st century, the main purpose of which is to gradually optimize the small-scale and scattered exploration pattern (Zhu and Mo, 2017). In the year 2001, the PRC government issued the National Mineral Resources Plan (2001-2010), began to introduce spatial policy areas to regulate mineral resources exploration. Exploration/mining areas were classified into three groups, i.e., those where exploration of mineral resources are (1) encouraged, (2) restrained and (3) prohibited (for ecological/environmental conservation). In 2005, for interestedly resolving a number of prominent problems in coal industry, and guaranteeing national economic development, the PRC State Council proposed a goal to construct 13 large-scale coal planning regions (General Office of the PRC State Council, 2005). Based on this experience, the Chinese government explored to construct planning regions among other major mineral resources. In January 2009, the National Mineral Resources Plan (2008-2015) was issued (Ministry of Natural Resources of PRC, 2009), with a goal to establish 75 mining economic areas. However, because of the 
unclear boundary and lack of following promoting policies (Nie et al., 2015), its due role has not adequately played out. Energy and resource planning regions are upgraded version of the mining economic areas. The 7 gold resource planning regions defined are part of China's 103 energy and resource planning regions that proposed in 2016, and the establishment aims to: (1) guarantee the baseline of national gold resource supply; (2) promote sizable and intensive gold resource development, and completely resolve the problem of small-scale disorderly mining; (3) implement China's regional coordinated development strategy and promote the coordinated development of regional mining economy.

In China, previous research was focused on the delineation of mining economic areas. Wang et al. (2011) proposed the three-level mining economic delineation scheme based on the 75 mining economic areas; Song et al. (2014) suggests using ArcGIS technology and multivariate statistical analysis to complete the delineation work. Some other scholars also put forward some basis and principles of delimiting mining economic areas (Cao and $\mathrm{Li}, 2015)$. Since the concept of energy and resource planning regions was put forward, researchers began to pay more attention to its delineation issue. Ma (2015) has defined 11 iron ore resource planning regions nationwide by using SOFM cluster analysis method; Luo et al. (2016) proposed 27 energy and resource planning regions in Sichuan Province based on the analysis of some mineral information maps. Wang and Niu (2016) demarcated 42 non-ferrous metal resource planning regions by establishing an evaluation index and using map superposition method.

It can be seen that spatial area for mineral resource management in the UK, the United
States and Australia are mainly focused on the protestation of domestic minerals from sterilization by other forms of development. While in China, their tasks are more diverse, this requires that the delineation work must satisfy more needs. The previous research has taken various mineral resource information into account when delimiting planning regions, but their methods are mainly qualitative, and unable to meet multiobjective requirements.

The spatial-policy-area delineation methods in the current studies can roughly be divided into four categories namely: (1) the experience of relevant experts, which is largely affected by the expert's knowledge and individual experience (Cowling et al., 2003; Wang et al., 2011); (2) by creating a set of predefined standards (Cao and $\mathrm{Li}, 2015$; Brown et al., 1995; Eken et al., 2004; Myers et al., 2000), e.g. to make some strict delimitation principle, or some standards based on the distribution of the natural resource itself. For instance, in the UK, the boundary of Mineral Safeguarding Areas is determined by applying a specified buffer to the mineral resource outline, for the sand and gravel, the buffer is set to $250 \mathrm{~m}$; (3) to identify areas that attain near-optimal solutions for delineation targets, e.g., spatial optimization model (Toregas et al., 1971; Church and Revelle, 1974; Zvi et al., 2019; Okabe and Suzuki,1997; Watts et al., 2009). For instance, Watts et al. (2009) identify biodiversity conservation zones that could minimize the total cost while achieve a variety of conservation and land-use objectives; (4) adopting methods such as spatial overlying or clustering analysis (Xiang et al., 2015; Zhang, 2014), as used in the delimitation of ecological redlines by Yang et al. (2018). Among these four categories of 
methods, the method (3) is quantitative and can satisfy multiple objectives, which are the most suitable for the delineation of gold resource planning regions. Therefore, this study proposes to use method (3), and design a spatial delineation method that can achieve the three aims of gold resource planning regions above-mentioned.

\section{METHODOLOGY}

\section{Study Methods}

Spatial delineation of the gold resource planning regions in this study is in line with the following rules:

(i) For a certain planning region, the geographic distance from all its mining rights to its center is shorter than to the center of the adjacent planning region. This rule ensures the spatial concentration of gold mining rights in the planning regions. Minimizing the areal scale can improve the focus of resource planning regions for effective management, and thereby boost the scale and intensity of mineral resources exploitation, in accordance with the industrial cluster theory (Helsley, 2004).

(ii) The size of each planning region should be similar. This corresponds to the "coordinated development of regional economy" strategy, which is one of the current national priorities in China (Xi, 2017). Similar size of the gold resource planning regions can avoid large differences in regional economic development.

(iii) The production capacity in the gold resource planning regions have to be above a certain proportion of the total gold production capacity in the country, which set a baseline for guaranteeing domestic resource supply.

The spatial delineation of gold resource planning regions can be regarded as a multiobjective spatial optimization problem, which needs to be calculated by several methods. In the published spatial optimization methods, The Voronoi diagram (Zvi et al., 2019; Okabe and Suzuki., 1997) is able to comply with Rule No. (i); GIS buffer analysis (Zhou et al., 2017) can better comply with Rules No. (ii) and (iii). Both methods have been extensively applied to the fields of urban planning, ecological protection, flood and disaster prevention/mitigation ( $\mathrm{Li}$ et al., 2016). This study attempts to introduce both methods into delineation of the gold resource planning regions.

The Voronoi diagram is also called the Thiessen polygon, aims to divide a study area into polygons that are defined by Rule No. (i) (Voronoi,1909; Okabe et al., 2009). The Voronoi diagram is generated with ArcGIS software to identify the largest threshold of each gold resource planning region, and the planning region boundary cannot exceed its Thiessen polygon scale.

Based on the Voronoi diagram generated, buffer analysis is performed to constrain the scope of gold resource planning regions. Buffer analysis is a polygon layer on the basis of point, linear and planar entity, and automatically creates a buffer area of a certain width around it, thus can identify and analyze the possible association rules between spatial objects and surrounding things, environment, as well as the scope and degree of their influence (Wu et al., 2001; Bonham-Carter, 1994). In terms of the procedures:

(1) set a minimum percentage of production capacity in the gold 
resource planning regions to the total capacity of China (hereinafter referred to as goal value);

(2) create a buffer zone around the planning region center, and calculate the minimum buffer radius to achieve the goal value.

To implement Rule No. (ii), this study set the radius of each planning region buffer into a single constant value. For the steps of analysis:

(1) calculate the Euclidean distance between the center of each gold resource planning region and the gold mining districts in its Thiessen polygon;

(2) take the planning region center as the center of a circle, and take a certain distance as the radius to create a buffer zone, and calculate the production capacity of the mining districts in the buffer zone;

(3) take $10 \mathrm{~km}$ as step length to enlarge the radius of the buffer zone, repeat steps (2) and (3) until the radius reaches its maximum distance. In this study, the minimum radius is 0 , while the maximum radius is the Euclidean distance between each gold resource planning region and its furthest gold mining right;

(4) take the radius as X-axis and goal value as $y$-axis to generate a $2 \mathrm{D}$ map, which yield the radii of gold resource planning regions under different goal values. Filter the mining rights in each gold resource planning region within such radius, and draw the minimum outsourcing polygon. This gives the spatial scope of gold resource planning regions under their corresponding goal values.

\section{Data Sources}

The location and production capacities of gold mining rights in China are the main two indices in this study. The base map uses the PRC administrative map 2006, and the districts under the jurisdiction of the same prefecture level city are merged into one polygon. This results in 2366 county-level administrative regions. Location of the gold mining rights in China and their production capacities data were collected from PRC National Mineral Exploration and Mining Information Publicity System (http://kyqgs.mnr.gov.cn/), and the data cover the whole mainland China.

\section{RESULTS AND DISCUSSION}

\section{Spatial Delineation of Gold Resource Planning Regions}

The 7 gold resource planning regions are namely Zhaoyuan-Laizhou (Shandong), Xiaoqinling-Xiongershan (Henan), Zijinshan (Fujian), Zhenfeng-Pu'an (Guizhou), Eastern Kunlun (Qinghai), Southern Gansu, Pingjiang-Liling (Hunan) (Fig. 1). TheVoronoi diagram was constructed based on the center point of the planning regions, and the result are shown in Figure 1.

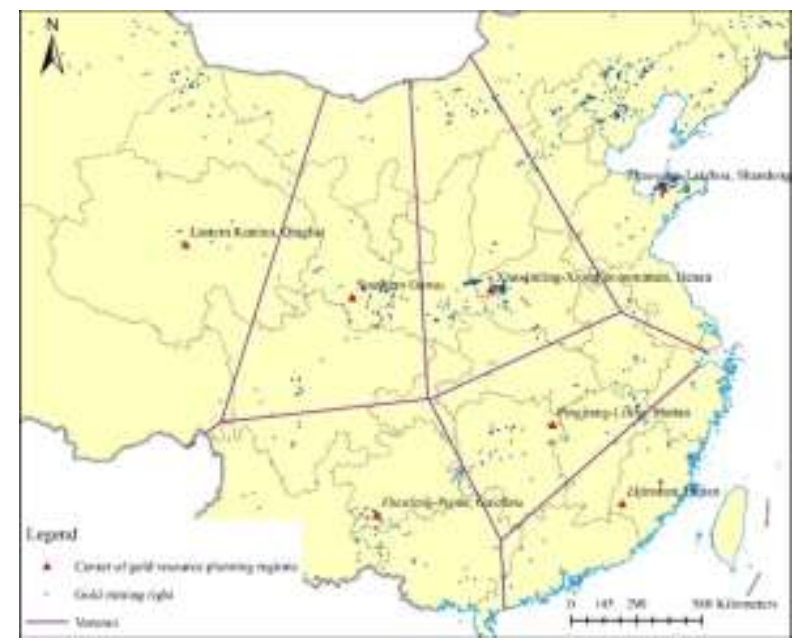


Figure 1. Voronoi diagram of the 7 gold resource planning regions in China.

The $\mathrm{x}$-axis was taken as the radius of gold resource planning regions and y-axis as the goal value (Figure. 2). As shown in Figure. 2, with increasing radius of the buffer zone, the goal value increases rapidly first, reaching $60 \%$ when the radius reaches $\sim 400$ $\mathrm{km}$. When the radius reaches $>900 \mathrm{~km}$, the growth of goal value becomes very slow. Considering that gold is a major mineral in short supply in China, with a middle degree of external dependence, and the spatial distribution of gold mining rights is relatively scattered, this study sets the goal value between $40 \%$ and $60 \%$, to explore the boundary scales of gold resource planning regions under $60 \%, 50 \%$ and $40 \%$ goal values. It is calculated that, when goal value $=$ $60 \%$, the buffer zone radius of the 7 gold resource planning regions is required to reach $400 \mathrm{~km}$; when goal value $=50 \%$, the buffer zone radius is required to reach $190 \mathrm{~km}$; when goal value $=40 \%$, the buffer zone radius is required to reach $70 \mathrm{~km}$.

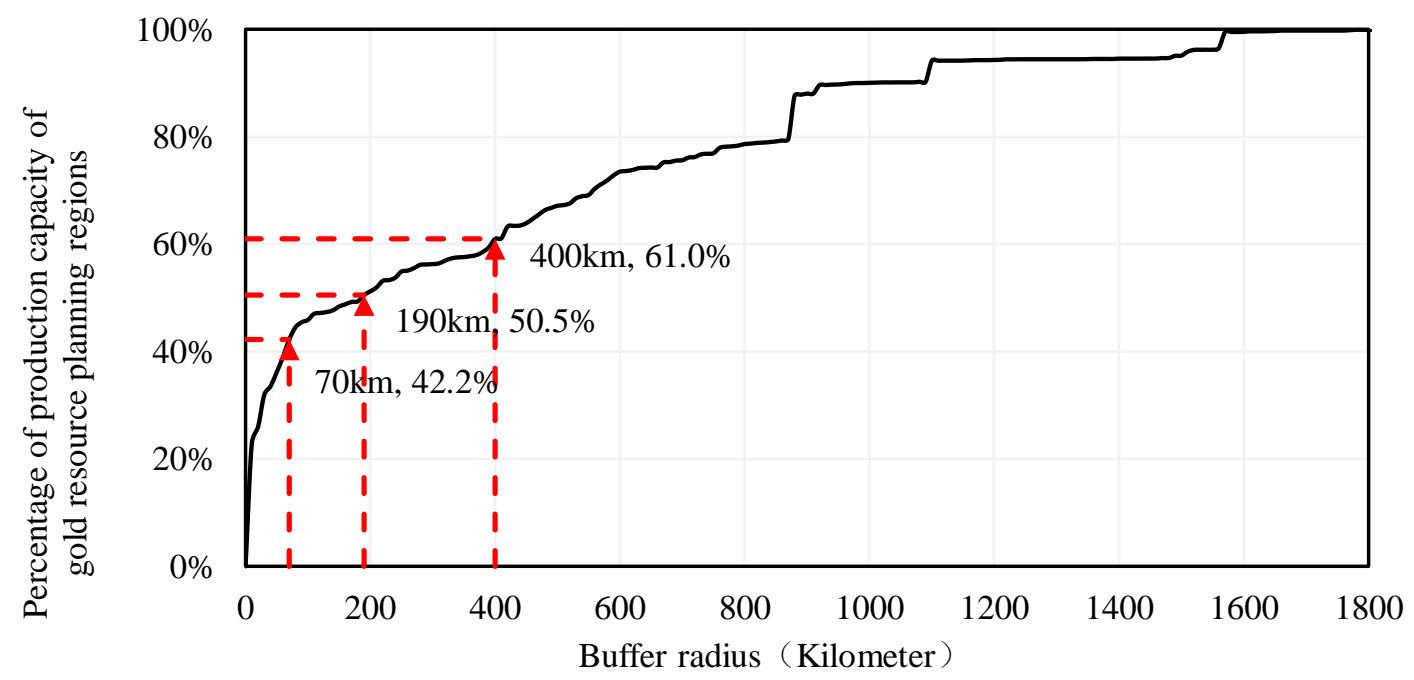

Figure 2. Graph of goal value variation with different buffer zone radius.

After we select the gold districts in the buffer zone, and calculate the minimum outsourcing polygon of the mining districts, we can get the boundary scales of the gold resource planning regions under $60 \%, 50 \%$ and $40 \%$ goal values, as shown in Figure 3. It should be noted that Zijinshan planning region has only two mining rights and one single mining right with goal value of $50 \%$ and $40 \%$ respectively, which cannot automatically generate the smallest outsourcing polygon, hence, the spatial scopes in these two cases were not shown in the Figure. 


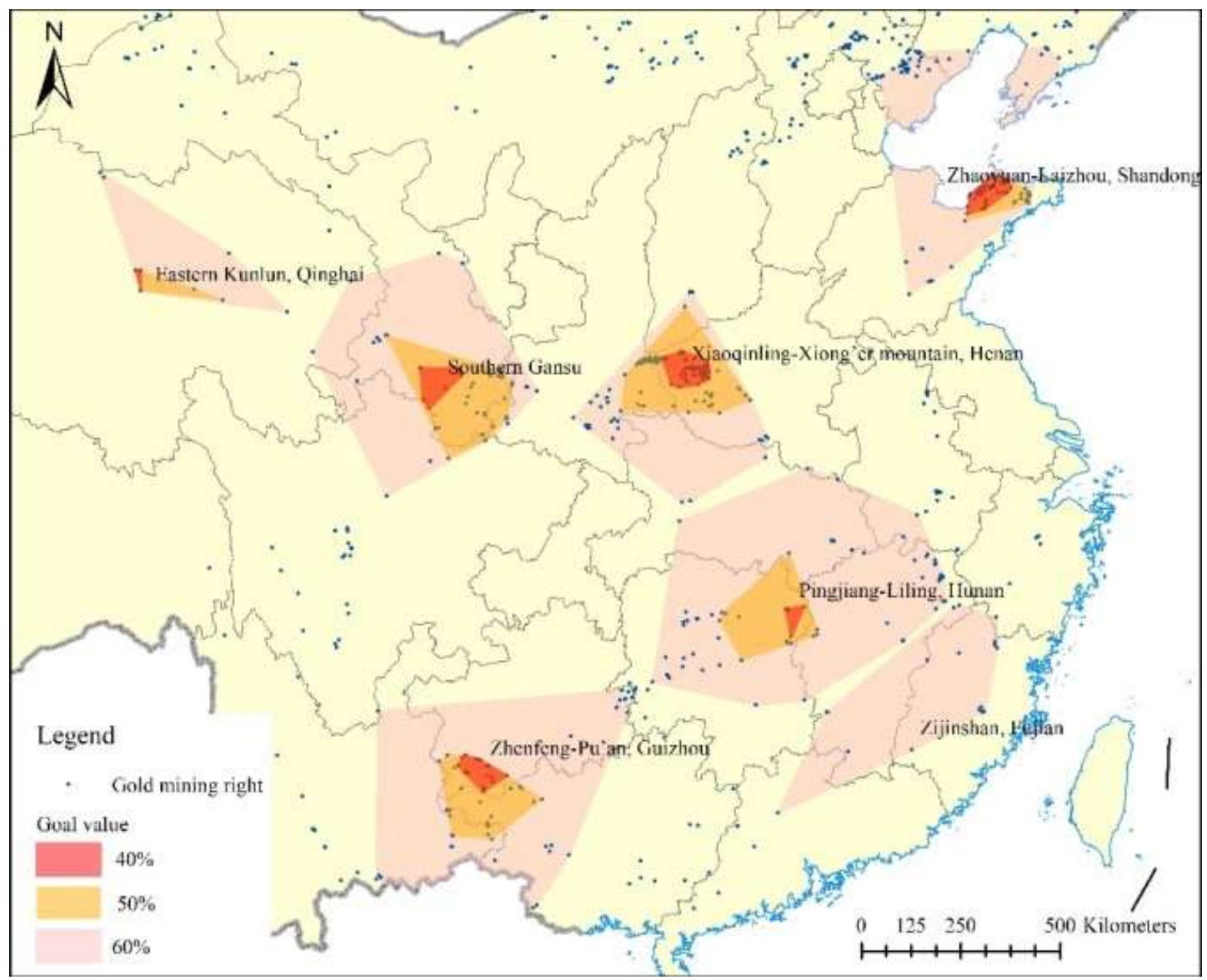

Figure 3. Scales of gold resource planning regions with goal values of $60 \%, 50 \%$ and $40 \%$

the highest gold ore production capacities

Assessment and Analysis to Delineation

\section{Results}

Basic Index Statistics

(1) Planning regions delineation with goal value of $60 \%$

There are a total of 582 gold mining rights in the 7 gold resource planning regions, accounting for $53.2 \%$ of the country. Among the 7 planning regions, Zhaoyuan-Laizhou and Xiaoqinling-Xiongershan have more than 100 mining rights, followed by PingjiangLiling, (> 80), Southern Gansu and ZhenfengPu'an (each $>60$ ). The Eastern Kunlun has the least number of gold mining rights (10).

The total gold ore production capacities in the 7 planning regions are $101.33 \mathrm{Mt}$, accounting for $61.0 \%$ of China (Table 1). Among the 7 planning regions, Zijinshan has
(38.2 Mt, $23.0 \%$ of national total), followed by Zhaoyuan-Laizhou (23.23 Mt, $14.0 \%$ of national total). Xiaoqinling-Xiongershan and Southern Gansu also have more than $10 \mathrm{Mt}$ capacities. The Eastern Kunlun has the least gold ore production capacities $(1.31 \mathrm{Mt}, 0.8 \%$ of national total).

In terms of areal size, the 7 planning regions cover a total area of 1,189,941 km², $12.4 \%$ of national total. Among the 7 planning regions, Pingjiang-Liling is the largest $\left(\sim 313,830 \mathrm{~km}^{2}\right)$, followed by Zhenfeng-Pu'an $\quad\left(\sim 246,141 \quad \mathrm{~km}^{2}\right) \quad$ and Southern Gansu $\left(\sim 210,746 \mathrm{~km}^{2}\right)$, and the remaining four planning regions are under $200,000 \mathrm{~km}^{2}$. The Eastern Kunlun is the smallest $\left(\sim 61,499 \mathrm{~km}^{2}\right)$. 
Table 1. Statistics of 7 Gold Resource Planning Regions with A Goal Value of $60 \%$

\begin{tabular}{lcccc}
\hline \multicolumn{1}{c}{ Name } & $\begin{array}{c}\text { No. of Mining } \\
\text { Rights }\end{array}$ & $\begin{array}{c}\text { Production Capacity } \\
\text { of Ore } \\
(\mathbf{1 0 0 0 0 ~ t )}\end{array}$ & $\begin{array}{c}\text { Percentage (\%) of } \\
\text { National Total }\end{array}$ & $\begin{array}{c}\text { Size } \\
\left(\mathbf{1 0 , 0 0 0} \mathbf{~ k m}^{\mathbf{2}}\right)\end{array}$ \\
\hline $\begin{array}{l}\text { Zijinshan, Fujian } \\
\text { Zhaoyuan-Laizhou, }\end{array}$ & 18 & 3820 & $23.0 \%$ & 119384 \\
$\begin{array}{l}\text { Shandong } \\
\text { Xiaoqinling- }\end{array}$ & 165 & 2323 & $14.0 \%$ & 99854 \\
$\begin{array}{l}\text { Xiongershan, Henan } \\
\text { Southern Gansu }\end{array}$ & 178 & 1181 & $7.1 \%$ & 138487 \\
$\begin{array}{l}\text { Zhenfeng-Pu'an, } \\
\text { Guizhou }\end{array}$ & 60 & 1134 & & 210746 \\
Pingjiang-Liling, Hunan & 62 & 844 & $6.8 \%$ & 246141 \\
Eastern Kunlun, Qinghai & 89 & 699 & $5.1 \%$ & 313830 \\
\hline \multicolumn{1}{c}{ Total } & 10 & 131 & $4.2 \%$ & 61499 \\
\hline
\end{tabular}

(2) Planning regions delineation with goal value of $50 \%$

There are a total of 384 gold mining rights in the 7 gold resource planning regions, accounting for $35.1 \%$ of the country. Among the 7 planning regions, XiaoqinlingXiongershan has the most (149), followed by Zhaoyuan-Laizhou (115). Southern Gansu and Zhenfeng-Pu'an have more than 40 mining rights, and the remaining three planning regions are under 30. Zijinshan has the least number of gold mining rights (2).

The total gold ore production capacities in the 7 planning regions are $83.92 \mathrm{Mt}$, accounting for $50.5 \%$ of China (Table 2). Among the 7 planning regions, Zijinshan has the highest gold ore production capacities (37.53 Mt, $22.6 \%$ of national total), followed

\begin{tabular}{lcccc}
\multicolumn{1}{c}{ Name 2. Statistics of 7 Gold Resource Planning Regions with A Goal Value of 50\% } \\
\hline & $\begin{array}{c}\text { No. of Mining } \\
\text { Rights }\end{array}$ & $\begin{array}{c}\text { Production } \\
\text { Capacity of Ore } \\
(\mathbf{1 0 0 0 0} \text { t) }\end{array}$ & $\begin{array}{c}\text { Percentage (\%) of } \\
\text { National Total }\end{array}$ & $\begin{array}{c}\text { Size } \\
\left(\mathbf{k m}^{\mathbf{2}}\right)\end{array}$ \\
\hline $\begin{array}{l}\text { Zijinshan, Fujian } \\
\text { Zhaoyuan-Laizhou, }\end{array}$ & 2 & 3753 & $22.6 \%$ & 5.3 \\
$\begin{array}{l}\text { Shandong } \\
\text { Xiaoqinling- }\end{array}$ & 115 & 1940 & $11.7 \%$ & 11091 \\
$\begin{array}{l}\text { Xiongershan, Henan } \\
\text { Southern Gansu }\end{array}$ & 149 & 974 & $5.9 \%$ & 50916 \\
$\begin{array}{l}\text { Zhenfeng-Pu'an, } \\
\text { Guizhou }\end{array}$ & 46 & 762 & $4.6 \%$ & 50671 \\
$\begin{array}{l}\text { Pingjiang-Liling, Hunan } \\
\text { Eastern Kunlun, Qinghai }\end{array}$ & 41 & 689 & $4.1 \%$ & 35066 \\
\hline \multicolumn{1}{c}{ Total } & 25 & 245 & $1.5 \%$ & 37367 \\
\hline
\end{tabular}

by Zhaoyuan-Laizhou (19.4 Mt, $11.7 \%$ of national total). Xiaoqinling-Xiongershan, Southern Gansu and Zhenfeng-Pu'an have more than $5 \mathrm{Mt}$ capacities. The Eastern Kunlun only has less than $1 \mathrm{Mt}$ gold ore production capacities.

In terms of areal size, the 7 planning regions cover a total area of $190,945 \mathrm{~km}^{2}$, $2.0 \%$ of national total. Among the 7 planning regions, Xiaoqinling-Xiongershan and Southern Gansu are the largest $(\sim 50,916$ $\left.\mathrm{km}^{2}\right)$, followed by Pingjiang-Liling $(\sim 37,367$ $\left.\mathrm{km}^{2}\right)$ and Zhenfeng-Pu'an $\left(\sim 35,066 \mathrm{~km}^{2}\right)$. As there are only two mining rights in Zijinshan, it is unable to define the minimum outsourcing polygon, the actual area of these two mining rights is used instead.

Table 2. Statistics of 7 Gold Resource Planning Regions with A Goal Value of 50\% 
(3) Planning regions delineation with goal value of $40 \%$

There are a total of 210 gold mining rights in the 7 gold resource planning regions, accounting for $19.2 \%$ of the country. Among the 7 planning regions, Zhaoyuan-Laizhou has the most (92), followed by XiaoqinlingXiongershan (71). The remaining planning regions are all under 30. Zijinshan has only one gold mining right.

The total gold ore production capacities in the 7 planning regions are $70.17 \mathrm{Mt}$, accounting for $42.2 \%$ of China (Table 3). Among the 7 planning regions, Zijinshan has the highest gold ore production capacities
(37.5 Mt, $22.6 \%$ of national total), followed by Zhaoyuan-Laizhou (17.53 Mt, $10.6 \%$ of national total). Besides, XiaoqinlingXiongershan has more than $5 \mathrm{Mt}$ capacities. The Eastern Kunlun has the lest gold ore production capacities.

In terms of areal size, the 7 planning regions cover a total area of $27956 \mathrm{~km}^{2}, 0.3 \%$ of national total. Among the 7 planning regions, Xiaoqinling-Xiongershan are the largest $\left(\sim 7,946 \mathrm{~km}^{2}\right)$, followed by Southern Gansu $\left(\sim 6,630 \mathrm{~km}^{2}\right)$ and Zhenfeng-Pu'an $\left(\sim 5,534 \mathrm{~km}^{2}\right)$. There is only one gold mining right in Zijinshan, the area of which is $5 \mathrm{~km}^{2}$.

Table 3. Statistics of 7 Gold Resource Planning Regions with A Goal Value of $40 \%$

\begin{tabular}{lcccc}
\hline \multicolumn{1}{c}{ Name } & $\begin{array}{c}\text { No. of Mining } \\
\text { Rights }\end{array}$ & $\begin{array}{c}\text { Production Capacity } \\
\text { of Ore } \\
(\mathbf{1 0 0 0 0 ~ t )}\end{array}$ & $\begin{array}{c}\text { Percentage (\%) of } \\
\text { National Total }\end{array}$ & $\begin{array}{c}\text { Size } \\
\left(\mathbf{k m}^{\mathbf{2}}\right)\end{array}$ \\
\hline $\begin{array}{l}\text { Zijinshan, Fujian } \\
\text { Zhaoyuan-Laizhou, }\end{array}$ & 1 & 3750 & $22.6 \%$ & 5.1 \\
$\begin{array}{l}\text { Shandong } \\
\text { Xiaoqinling- }\end{array}$ & 92 & 1753 & $10.6 \%$ & 5816 \\
$\begin{array}{l}\text { Xiongershan, Henan } \\
\text { Southern Gansu }\end{array}$ & 71 & 549 & $3.3 \%$ & 7946 \\
$\begin{array}{l}\text { Zhenfeng-Pu'an, } \\
\text { Guizhou }\end{array}$ & 11 & 434 & $2.6 \%$ & 6630 \\
Pingjiang-Liling, Hunan & 21 & 375 & $2.3 \%$ & 5534 \\
Eastern Kunlun, Qinghai & 10 & 132 & $0.8 \%$ & 1692 \\
\hline \multicolumn{1}{c}{ Total } & 4 & 24 & $0.1 \%$ & 333 \\
\hline
\end{tabular}

County-level Administrative Regions Involved in The Planning Regions

The county governments are the main policy-implementation and supervision bodies of gold resource planning regions, and the county-level administrative regions are the subject scope of gold resource planning regions. Therefore, it is necessary to make statistics on the county-level administrative regions involved in the planning regions, to find out who should take shoulders on the implementation of gold resource planning regions.
(1) Planning regions delineation with goal value of $60 \%$

A total of 168 county-level administrative regions are involved in the 7 planning regions with goal value of $60 \%$ (Table 4, Figure 4), among which the Pingjiang-Liling has the most (38), followed by Xiaoqinling-Xiongershan (35). Besides, the Zhaoyuan-Laizhou, Zhenfeng-Pu'an and Southern Gansu has also >20 county-level regions. The Zijinshan and Eastern Kunlun both have below 20 county-level regions. 
A total of 30 county-level administrative

(2) Planning regions delineation with goal value of $50 \%$

A total of 78 county-level administrative regions are involved in the 7 planning regions (Table 4, Figure 4), among which the Xiaoqinling-Xiongershan has the most (23), followed by Southern Gansu (17) and Zhenfeng-Pu'an (15). Zhaoyuan-Laizhou and Pingjiang-Liling both have 10 county-level regions. The Eastern Kunlun only has 1 county-level region.

(3) Planning regions delineation with goal value of $40 \%$

Table 4. Numbers of County Level Administrative Regions Involved in The Gold Resource Planning Regions

\begin{tabular}{lccc}
\hline \multicolumn{1}{c}{ Name } & $\begin{array}{c}\text { No. of Counties with } \\
\text { Goal Value of } \mathbf{6 0 \%}\end{array}$ & $\begin{array}{c}\text { No. of Counties with } \\
\text { Goal Value of 50\% }\end{array}$ & $\begin{array}{c}\text { No. of Counties with } \\
\text { Goal Value of 40\% }\end{array}$ \\
\hline Zijinshan, Fujian & 11 & 2 & 1 \\
Zhaoyuan-Laizhou, Shandong & 28 & 10 & 8 \\
Xiaoqinling-Xiongershan, & 35 & 23 & 7 \\
Henan & 25 & 17 & 5 \\
Southern Gansu & 27 & 15 & 6 \\
Zhenfeng-Pu'an, Guizhou & 38 & 10 & 2 \\
Pingjiang-Liling, Hunan & 4 & 1 & 1 \\
Eastern Kunlun, Qinghai & 168 & 78 & 30 \\
\hline \multicolumn{1}{c}{ Total } & & \\
\hline
\end{tabular}

regions are involved in the 7 planning regions (Table 4, Figure 4), which is 48 fewer than that of $50 \%$ goal value. Among the 7 planning regions, Zhaoyuan-Laizhou, Xiaoqinling-Xiongershan, Zhenfeng-Pu'an have more than 5 county-level regions, Zijinshan and Eastern Kunlun only have 1 county-level region. 


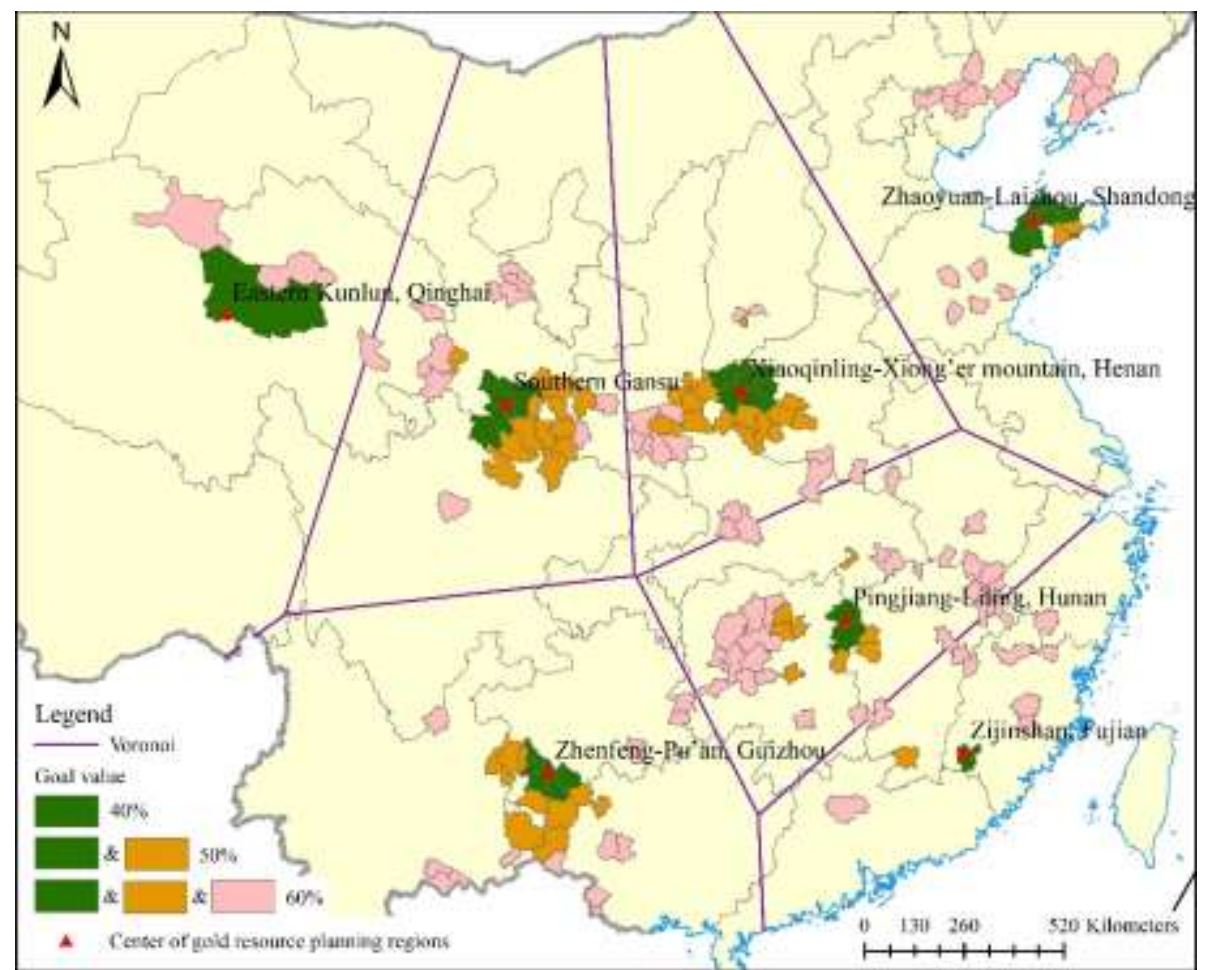

Figure 4. County-level administrative regions involved in the planning regions with goal values of $60 \%, 50 \%$ and $40 \%$.

\section{Comparison of Different Goal Values}

Table 5 compares the changes of mining rights number, the size of the 7 gold resource planning regions and the county-level regions number under the three goal values. It is easy to see that with the increase of the goal value, the three indices all increase greatly, among which the planning regions' size has the largest increase, followed by the increase of the county-level regions number, and the smallest increase of mining rights number. When the goal value is increased from $40 \%$ to $50 \%$, the size of the 7 planning regions increases by $772 \%$, the number of county- level regions increases by $260 \%$, and the number of mining rights increases by $83 \%$. When the goal value is increased from $50 \%$ to $60 \%$, the increased quantity of these three indices all increased, while the increased extend of these indices all decreased. Especially for the planning region size, the increased quantity is 94,6247 when the goal value changes from $50 \%$ to $60 \%$, four times more than that of the goal value changes from $40 \%$ to $50 \%$, but the increased extend is only about $1 / 2$ of the former. The increase of mining rights number has minimum difference under these two cases.

Table 5. Comparison of Indices of Gold Resource Planning Regions with 60\%, 50\% and 40\% Goal Values

\begin{tabular}{|c|c|c|c|c|c|c|}
\hline \multirow{2}{*}{ Index } & \multicolumn{2}{|c|}{$\begin{array}{l}\text { Mining Rights } \\
\text { Number }\end{array}$} & \multicolumn{2}{|c|}{ Planning region Size } & \multicolumn{2}{|c|}{$\begin{array}{c}\text { County-Level Regions } \\
\text { Number }\end{array}$} \\
\hline & $\mathbf{a}$ & b & $\mathbf{a}$ & b & $\mathbf{a}$ & b \\
\hline Increase (number) & 174 & 198 & $21,5736 \mathrm{~km}^{2}$ & $94,6247 \mathrm{~km}^{2}$ & 48 & 90 \\
\hline Increase $(\%)$ & $83 \%$ & $52 \%$ & $772 \%$ & $388 \%$ & $260 \%$ & $115 \%$ \\
\hline
\end{tabular}

Note: "a" refers to the parametric variation from $40 \%$ to $50 \%$ goal value; "b" refers to the parametric variation from $50 \%$ to $60 \%$ goal value. 


\section{CONCLUSION}

\section{Conclusions and Policy Recommendations}

The delineation work is essential for the subsequent management of gold resource planning regions. In this study, the Voronoi diagram and buffer analysis were performed to calculate the spatial scope of the 7 gold resource planning regions that proposed in the National Mineral Resources Plan (2016-2020) and satisfies multiple objectives, including spatial agglomeration of mining rights, regional coordinated development, and guarantee the domestic supply. The scope from both resource exploitation (mining right-level) and management (administrative county-level) perspectives were delineated under $60 \%, 50 \%$ and $40 \%$ goal values. The results show that: (1) Zijinshan, ZhaoyuanLaizhou and Xiaoqinling-Xiongershan are the best three planning regions to guarantee domestic baseline of gold resources; (2) with the increase of the goal value, the Countylevel administrative regions involved, the number of mining rights, and especially the planning region sizes all increase greatly, and their number increase with the goal value from $50 \%$ to $60 \%$ is more than that from $40 \%$ to $50 \%$ goal value, but their percentage increase is just the opposite.

Mineral resources management is an interdisciplinary subject of resources science and management science. In recent years, integration with economics, statistics, geography and other disciplines has become more common (Guo et al., 2016; Yokoi et al., 2018). Geographic theories, and statistic and spatial analysis methods can solve some problems in mineral resource management (Aroca and Atienza, 2011; Doraisami, 2015; De Souza Ramser et al., 2019). Mineral resources have obvious spatial properties. These spatial properties are the basis of mineral resource layout and partition management. Partition management is closely integrated with geography and follows the basic geographic theory. Compared with economics and statistics, there are fewer studies on the integration of geography and mineral resource management, and most studies on zoning are based on metallogenic theory. The spatial scope of gold resource planning regions is an exploratory study of the cross-fusion of mineral resources management and geography.

In terms of policy implications, firstly, this study can provide some reference for the Chinese government to select suitable spatial scope for gold resource planning regions. From the results, we can see that the higher the goal value, the larger the planning region size, the more the gold mining rights and county-level regions, which means more ecological environment impact cost (Liang et al., 2019), more land occupation and more management cost. For example, by comparing the results of gold resource planning regions at $60 \%$ and $50 \%$ goal values, although the former goal value is only slightly higher than the latter, the number of mining rights are 198 more, with 94,6247 $\mathrm{km}^{2}$ areal increase, and 90 more county-level regions. The government may take the management cost and increase of ecological environment impact cost into consideration, and choose a suitable goal value to delimit scientific and reasonable spatial scope of gold resource planning regions.

Secondly, the results of this study can also provide reference for the differential management of gold resource planning regions. As Zijinshan, Zhaoyuan-Laizhou and Xiaoqinling-Xiongershan have the largest gold production capacities, and were exploited before the other planning regions, we suggest that the key of management policy in these three areas is to improve the 
level of large-scale development and promote conservation and circulatory use of resources. For example, the government may make some incentive policies for large-scale mining enterprises and inhibit small-scale mining activities that are with low-standard resource management and safety practice, and to define a minimal mining-scale for newly-built mines to increase the proportion of large and medium mines. Meanwhile, the mining technology standard in these three areas should be above that of other planning regions to reduce environmental impacts. For Southern Gansu and Zhenfeng-Pu'an, which have medium gold production capacities, the key management policy is to guarantee stable production by the mining enterprises. We suggest that the government to carry out some protective measures for mining enterprises in these two planning regions to maintain their current production, and to encourage geological exploration. For Pingjiang-Liling and Eastern Kunlun, which have the lowest production capacities, the key is to increase geological exploration and resource evaluation to find more gold resources, and safeguard these prospective areas from other land development activities.

\section{REFERENCES}

Amiri H., Samadian F., Yahoo M., and Jamali S. J., (2019) "Natural resource abundance, institutional quality and manufacturing development: Evidence from resource-rich countries," Resources policy, 62, pp. 550560.

Aroca P., and Atienza M., (2011) "Economic implications of long distance commuting in the Chilean mining industry," Resources Policy, 36, 3, pp. 196-203.

Baker D., and Hendy B., (2005) "Planning for Sustainable Construction Aggregate Resource in Australia”, In: Sidwell, Anthony
Charles (Ed.), Proceedings of the Queensland University of Technology Research Week International Conference, Queensland University of Technology, Brisbane, Queenslan.

Blasi C., Marignani M., Copiz R., Fipaldini M., Bonacquisti S., Vico E. D., Rosati L., and Zavattero L., (2011) "Important plant areas in Italy: from data to mapping", Biological Conservation, 44(1), pp. 220-226.

Blotevogel H. H., (2006) "A re-orientation of spatial planning policy?: The new 'Concepts and Action Strategies for Spatial Development in Germany' under discussion”, Raumforschung und Raumordnung, 64(6), pp. 460-472.

Bonham-Carter G. F., (1994) "Geographic planning systems for geoscientist", Computer Methods in the Geosciences, 13, pp. 341343.

Brown A. F., Stillman R. A., and Gibbons D. W., (1995) "Use of breeding bird atlas data to identify important bird areas-a Northern England case-study", Bird Study, 42, pp. 132-143.

Cao W., and Li H., (2015) "The division basis and method of mining economic zone of China", Western Resource, 3, pp. 207-209.

Carroll H. B., and Johnson W. I., (1999) "Mineral Resource Planning System for Field Lab in the Osage Mineral Reservation Estate", NIPER/BDM-0278, National Petroleum Technology Program (U.S.), Tulsa, Oklahoma, the United States.

Church R., and Revelle C., (1974) "The maximal covering location problem", Papers of the Regional Science Association, 32, pp. 101118.

Cowling R. M., Pressey R.L., Sims-Castley R., le Roux A., Baard E., Burgers C. J., and Palmer G., (2003) "The expert or the algorithm? Comparison of priority conservation areas in the Cape Floristic Region identified by park managers and reserve selection software", Biological Conservation, 112(1-2), pp. 147167. 
Daw G., (2017) "Security of mineral resources: A new framework for quantitative assessment of criticality", Resources Policy, 53, pp. 173189.

De Souza Ramser C. A., Souza A. M., Souza F. M., Da Veiga C. P., and Da Silva W. V., (2019) "The importance of principal components in studying mineral prices using vector autoregressive models: Evidence from the Brazilian economy", Resources Policy, 62, pp. 9-21.

Doraisami A., (2015) "Has Malaysia really escaped the resource curse? A closer look at the political economy of oil revenue management and expenditures", Resources Policy, 45, pp. 98-108.

Dunn J. R., Cueman E. R., and Preston C. M., (1980) "Zoning for Mineral in Carroll County, Maryland," In: Proceedings of the Fourteenth Annual Forum on the Geology of Industrial Minerals, N. Y. State Mus. Bull., New York, Britain, 436, 3-5.

И. М. Е., and Li Z., (1985) "Iron ore supply areas of the Soviet Union and its development prospect", Conservation and Utilization of Mineral Resources, 1, pp. 4-7.

Eken G., Bennun L., Brooks T. M., Darwall W., Fishpool L. C., Foster M., Knox D., Langhammer P., Matiku P., Radford E., Salaman P., and Sechrest W., (2004) "Key biodiversity areas as site conservation targets”, Bioscience, 54, pp. 1110-1118.

European Commission, (1999) The EU compendium of spatial planning systems and policies, Liverpool University Press, Liverpool, The United Kingdom.

General Office of the State Council of the People's Republic of China, Several Opinions of the State Council on Promoting the Healthy Development of the Coal Industry, [Online]. Available: http://www.gov.cn/zwgk/2005-

09/08/content_30251.htm [Accessed: 200509-08].

Guo J., Yan W., Cui R., Liu Z., Zhou Q., and Liu W., (2019) "Outlook and Overview of
Mineral Resources Situation of China", Land and Resources Information, (12), pp. 46-51.

Guo R., Luo D., Zhao X., and Wang J., (2016) "Integrated Evaluation Method-Based Technical and Economic Factors for International Oil Exploration Projects", Sustainability, 8, pp. 188.

He S., Su Y., and Min Q., (2019) "Boundary, zoning, and land use management of the China National Parks: Learning from Nature Reserve and Scenic Areas", Acta Ecologica Sinica, 39(4), pp. 1318-1329.

Helsley R. W., (2004) "Economics of agglomeration: cities, industrial location and regional growth", Journal of Economic Geography, 4(3), pp. 345-349.

Knight A. T., Cowling R. M., Rouget M., Balmford A., Lombard A. T., and Campbell B. M., (2008) "Knowing but not doing: selecting priority conservation areas and the research-implementation gap", Conservation Biology, 22(3), pp. 610-617.

Koyama Y., (2011) "What is the so-called national comprehensive development plan (part one)?", Land Comprehensive Research, Spring, pp. 18-32.

Li N., Bagas L., Lindsay M., Wedge D., Bai L., and Song X., (2016) "An irregular triangle mesh buffer analysis method for boundary representation geological object in threedimension", Earth Science Informatics, 10(2), pp. 149-167.

Liang W., Luo S. and Zhao G., (2019) "Evaluation of Cleaner Production for Gold Mines Employing a Hybrid Multi-Criteria Decision Making Approach", Sustainability, 11, pp. 146.

Luo D., Cheng L., Liu H., and Liang Y., (2016) "Partitioning and Evaluation of Mineral Exploration and Exploitation Bases in Sichuan Province", Acta Geologica Sichuan, 36(4), pp. 689-693.

Ma J., (2015) Study on Division of China Iron ore Exploration and Development Base using Cluster Analysis, Thesis (Master's), China 
University of Geosciences (Beijing), Beijing, China.

Makarov A. A., (2009) "Science and technology forecasts and problems of Russia's energy development up to 2030", Herald of the Russian Academy of Sciences, 79(2), pp. 99108.

McEvoy F. M., Cowley J., Hobden K., Bee E. J., and Hannis S. D., (2007) A guide to mineral safeguarding in England, British Geological Survey Commissioned Report.

Meng X., Hou H., and Wu S., (2018) "Discussion on "green" thoughts in the development of mining industry", China Mining Magazine, 27(8), pp. 85-87.

Ministry of Natural Resources of PRC, National Mineral Resources Plan (2008 2015), [Online]. Available: http://www.mnr.gov.cn/gk/tzgg/200901/t200 90107 1989949.html [Accessed: 2009-0107].

Myers N., Mittermeier R. A., Mittermeier C. G., Da Fonseca G., and Kent J., (2000) "Biodiversity hotspots for conservation priorities", Nature, 403, pp. 853-858.

Nie B., Zhou J., Wang W., and Feng Y., (2015) "A general assessment of the development status of 75 mining economic zones in China", In: Collection of 2015 Academic Annual Meeting of Chinese Society on Economics of Geology \& Mineral Resources, Chinese Society on Economics of Geology \& Mineral Resources, Beijing, China, pp. 8695.

Okabe A., Boots B., Sugihara K., and Chiu S. N., (2009) Spatial tessellations: concepts and applications of Voronoi Diagrams, John Wiley \& Sons Ltd., New York, USA.

Okabe A., and Suzuki A., (1997) "Locational optimization problems solving through Voronoi diagrams", European Journal of Operational Research, 98, pp. 445-456.

Pian H., and Santosh M., (2019) "Gold deposits of China: Resources, economics, environmental issues, and future perspectives", Geological Journal, pp. 1-12.
PRC State Council, Reply on the National Mineral Resources Plan (2016-2020), [Online]. Available: http://www.gov.cn/zhengce/content/201611/08/content 5129991.htm [2016-11-08].

Roberts C. M., (2002) "Marine Biodiversity Hotspots and Conservation Priorities for Tropical Reefs", Science, 295, pp. 12801284.

Schouten M. A., Barendregt A., Verweij P. A., Kalkman V. J., Kleukers R. M. J. C., Lenders H. J. R., and Siebel H. N., (2010) "Defining hotspots of characteristic species for multiple taxonomic groups in the Netherlands", Biodiversity and Conservation, 19(9), pp. 2517-2536.

Scott M., and Dimitrakopoulos R., (2001) "Quantitative Analysis of Mineral Resources for Strategic Planning: Implications for Australian Geological Surveys", Natural Resources Research, 10(3), pp. 159-177.

Shafer C. L., (1999) "US national park buffer zones: historical, scientific, social, and legal aspects", Environmental Management, 23(1), pp. 49-73.

Shelford V. E., (1941) "List of reserves that may serve as nature sanctuaries of national and international importance, in Canada, the United States, and Mexico", Ecology, 22, pp. 100-107.

Shen L., Kong H., Wang J., Huang X., and Hu K., (2016) "The status and achievements of green mines and mining ethics in China", $J$. Resour. Ecol. 7(5), pp. 317-322.

Shen L., Zhang H., Zhong S., and Hu S., (2018) "Strategic thinking on the security of natural resources of China in the New Era", Journal of Natural Resources, 33(5), 721-734.

Shropshire County Council and Telford \& Wrekin Council, (2000) Shropshire,Telford \& Wrekin Minerals Local Plan 1996 - 2006.

Toregas C., Swain R., ReVelle C., and Bergman L., (1971) "The location of emergency service facilities", Operations Research, 19, pp. $1363-1373$. 
UNESCO, (1974) Task force on: criteria and guidelines for the choice and establishment of biosphere reserves, No.22, Final report, MAB report series UNESCO, Paris, France.

Voronoi G., (1909) "Nouvelles applications des paramètres continus à théorie des formes quadratiques. Deuxième Mémoire. Recherches sur les paralléloèdres primitifs", Journal für die Reine und Angewandte Mathematik (Crelles Journal), 136, pp. 67182.

Wagner H., Tiess G., Šolar S., and Nielsen K., (2006) "Minerals Planning Policies in Europe", Materials and Geoenvironment, 52(3), pp. 607-620.

Wang C., and Niu L., (2016) "Study on GISbased regionalization methods for nonferrous metal resources exploration and exploitation bases", Mineral Exploration, 7(1), pp. 191-197.

Wang D., Wang W., and Chen W., (2019) "Supply security of strategic metal ores in China", Resources \& Industries, 21(3), pp. 22-30.

Wang K., Zhou J., and Guo Y., (2011) "Study on the delimitation of mining economic regions of China”, China Mining Magazine, 20(1), pp. 14-18,.

Wang X., and Chen X., (2019) "An evaluation index system of China's development level of ecological civilization", Sustainability, 11, pp. 2270.

Watts M. E., Ball I. R., Stewart R. S., Klein C. J., Wilson K., Steinback C., Lourival R., Kircher L., and Possingham H. P., (2009) "Marxan with zones: software for optimal conservation-based land- and sea-use zoning", Environmental Modelling \& Software, 24, pp. 1513-1521.

Weber L., Holnsteiner R., and Reichl C., (2008) "Der Österreichische Rohstoffplan (The Austrian Mineral Resources Plan)", Joannea Geol. Paläont. 10, pp. 79-84.

Wrighton C. E., Bee E. J., and Mankelow J. M., (2014) "The development and implementation of mineral safeguarding policies at national and local levels in the United Kingdom", Resources Policy, 41, pp. 160-170

Wu L., Liu Y., and Zhang J., (2001) Geographic Planning system theory, $1^{\text {th }}$ Edition, Science Press, Beijing, China.

Wu S., and Zhang Y., (2019) "Distribution and management policy of energy resource bases in China", Strategic Study of Chinese Academy of Engineering, 21, pp. 81-87.

Xi J., Winning a Comprehensively Completed Well-off Society and Winning the Great Victory of Socialism with Chinese Characteristics in the New Era-Report at the 19th National Congress of the Communist Party of China, [Online]. Available: hhttp://www.gov.cn/zhuanti/201710/27/content_5234876.htm_[Accessed: 2017-10-18]

Xiang J., Li J., and Zeng J., (2015) "Research on the zone method and application of successive areas of mineral resources", Scientific and Technological Management of Land and Resources, 32(3), pp. 110-117.

Yang Q., Zhang M., and Wang X., (2018) "Technical points for defining redlines and boundary of water ecological protection", China Water Resources, (11), pp. 19-22.

Yokoi R., Nakatani J., and Moriguchi Y., (2018) "Calculation of Characterization Factors of Mineral Resources Considering Future Primary Resource Use Changes: A Comparison between Iron and Copper", Sustainability, 10, pp. 267.

Zhang R., (2014) Succession areas of important mass mineral resources comprehensive assessment and regionalization, Thesis $(\mathrm{PhD})$, China University of Geosciences, Wuhan, China.

Zhou X., Li S., Fan Y. F., Liu B., Zhang B. Y., and Li B., (2017) "Tourism Route Decision Support Based on Neural Net Buffer Analysis", Procedia Computer Science, 107, pp. 243-247.

Zhu Q., (2016) "Mineral resources development layout and system optimization", Natural 
Resource Economics of China, 29(1), pp. 4650.

Zhu S., and Mo D., (2017) "Research status of optimal layout of mineral resources exploration and exploitation in China", World Nonferrous Metals, (19), pp. 170-172.
Zvi D., Pawel K., and Said S., (2019) "The planar multiple obnoxious facilities location problem: A Voronoi based heuristic", Omega, $\quad 87, \quad$ pp. 105-116. 